\title{
A Wireworm Glyphonix bimarginatus (Schaeffer) (Insecta: Coleoptera: Elateridae) ${ }^{1}$
}

\author{
Dakshina R. Seal and Rafia A. Khan²
}

\section{Introduction}

Glyphonix bimarginatus (Figure 1) is a common click beetle pest of various economically important crops. The larvae of click beetles (Coleoptera: Elateridae) are elongated, wire-like and commonly known as wireworms. Wireworms are considered as subterranean economic pests during their larval stages in many parts of the world including the United States. The larvae of Glyphonix bimarginatus are commonly found with larvae of other click beetles in the field. Larvae of Glyphonix bimarginatus occurs in soil rich in organic matter and rarely in sandy soil. Young roots and germinating seeds are commonly fed upon by the larvae.

\section{Distribution}

Glyphonix bimarginatus occurs in Florida, Georgia, North Carolina, South Carolina, Virginia and Alabama (Deen and Cuthbert 1955, Chalfant et al. 1990, Herbert et al. 1992, Willis et al. 2010a, Willis et al. 2010b).

\section{Life Cycle and Biology}

\section{Adults}

The Glyphonix bimarginatus adult (Figure 1) is a small insect with a size ranging from 5 to $10 \mathrm{~mm}$, depending on its larval host, the season of the year and the previous history of the field in which they occur. Summer and fall populations are comprised of smaller sized individuals than winter and spring populations (mean 9 and $10 \mathrm{~mm}$, respectively). Glyphonix bimarginatus has three to four generations per year. Egg to adult development requires three to four months (Seal 1990). Adults do not feed directly on crops. Females of Glyphonix bimarginatus oviposit eggs near a food source such as young roots and tubers or residue of previous crops (Chalfant et al. 1990).

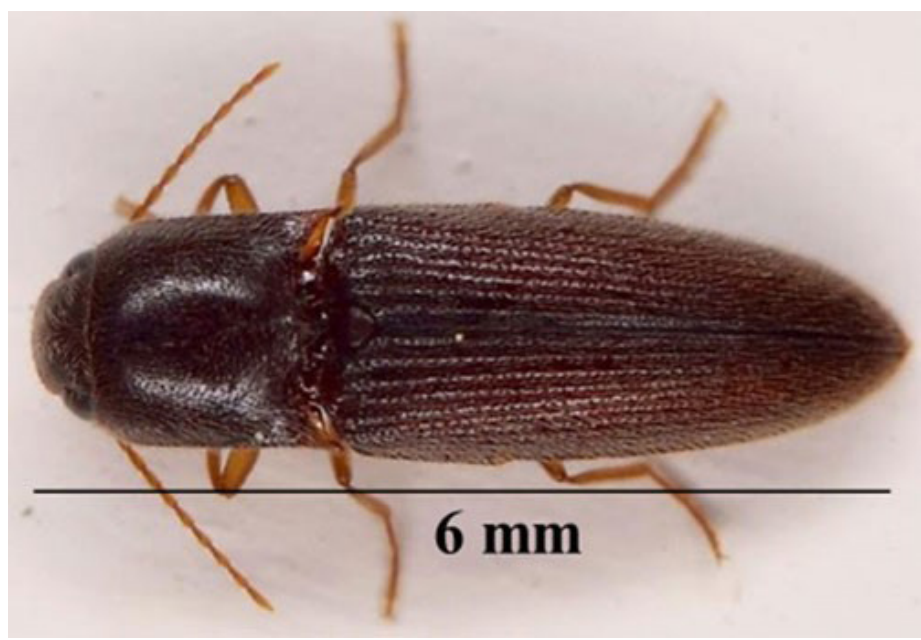

Figure 1. Adult Glyphonix bimarginatus (Schaeffer). Credits: Dakshina R. Seal, UF/IFAS

1. This document is EENY-723, one of a series of the Department of Entomology and Nematology, UF/IFAS Extension. Original publication date January 2019. Visit the EDIS website at https://edis.ifas.ufl.edu for the currently supported version of this publication. This document is also available on the Featured Creatures website at http://entomology.ifas.ufl.edu/creatures.

2. Dakshina R. Seal, associate scientist; and Rafia A. Khan, graduate research assistant; UF/IFAS Tropical Research and Education Center, Homestead, FL 33031.

The Institute of Food and Agricultural Sciences (IFAS) is an Equal Opportunity Institution authorized to provide research, educational information and other services only to individuals and institutions that function with non-discrimination with respect to race, creed, color, religion, age, disability, sex, sexual orientation, marital status, national origin, political opinions or affiliations. For more information on obtaining other UF/IFAS Extension publications, contact your county's UF/IFAS Extension office. 


\section{Eggs}

In all instances, eggs are laid singly in soil crevices and are attached to the growing roots of a host plant or plant residue. Eggs are laid between 5 and $10 \mathrm{~cm}$ below the soil surface (Seal 1990).

\section{Larvae}

First instar larvae are found between 50 and $100 \mathrm{~mm}$ below the soil surface. Glyphonix bimarginatus larvae feed on small delicate roots of host plants or on decaying plant residue. They make shallow and narrow feeding holes on sweet potato roots. A final instar larva measures 6 to 14 $\mathrm{mm}$ (Figure 2). The frontal suture (an external line-like groove in the body wall in the head region, is shaped like an inverted $U$ ) of the final instar larva is elliptical and does not touch the post occipital suture (the transverse suture on the head immediately posterior to the occipital suture, a transverse suture in the posterior part of the head) (Figure 3). Anteriorly, one pair of setae (bristle) is on each side, below the mandibular (jaw, one of the anterior pair of paired mouthpart structures) region. There are two setae near the margin of the gena (the part of the head on each side below and behind the compound eyes) and five setae near the post occipital sulcus (a groove formed by an infolding of the body wall). On the post genal (a sclerite on the posterior lateral surface of the head) region, five setae are visible. The antennae are three segmented, each segment having a seta. A short papilla is located at the tip of the second antennal segment.

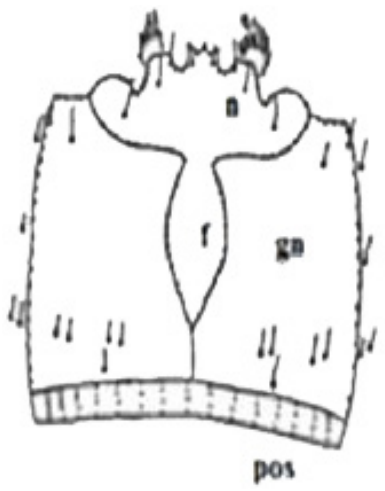

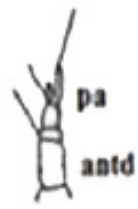

ant
Figure 2. Head of the final instar larva of Glyphonix bimarginatus (Schaeffer), dorsal view showing frontal suture, gena and postoccipital sulcus ( $n=$ nasale, $g n=g e n a$, pos=post gena (A). Antenna of the final instar larva of Glyphonix bimarginatus ( $p a=$ =papilla, ant=antenna, antd=antenna dorsal, antv=antenna ventral) (B). Credits: Dakshina R. Seal, UF/IFAS

The mandible has a tooth (Figure 4). Dorsally, one pair of setae is visible on mandible. A hairy tuft is present at the base of the mandible. There are two pairs of setae at the base of the submentum (the basal part of the labium i.e. one of the mouthparts). The post genal plate lateral to the submentum bears five setae near the anterior margin. The scutum (the middle division of thoracic notum i. e. the dorsal sclerite of a thoracic segment) contains six setae near the pre-scutellar sulcus on each side of the mid-dorsal line. There are two sets of setae near the scuto-scutellar sulcus on each half (Figure 5). The arrangement of setae on the first abdominal tergite is similar to that on the pronotum (the dorsal sclerite of the pro-thorax). There are six setae at the anterior margin and four setae at the posterior margin. The ninth abdominal segment is rounded, tapering posteriorly with a point (Figure 6). The arrangement of setae on the dorsal and ventral surfaces is almost identical, thus forming a continuous ring around the segment. In the first ring, there are four setae on the dorsal surface and four setae on the ventral surface. In the second ring, there are four setae on the dorsal surface and five setae on the ventral surface. The numbers of setae on the dorsal and ventral surfaces are four and six, respectively in the third ring. The numbers of setae in the fourth and fifth rings are equal on the dorsal and ventral surfaces. The pseudopod on the ventral surface is eversible and surrounded by a ring of setae (Seal 1990).
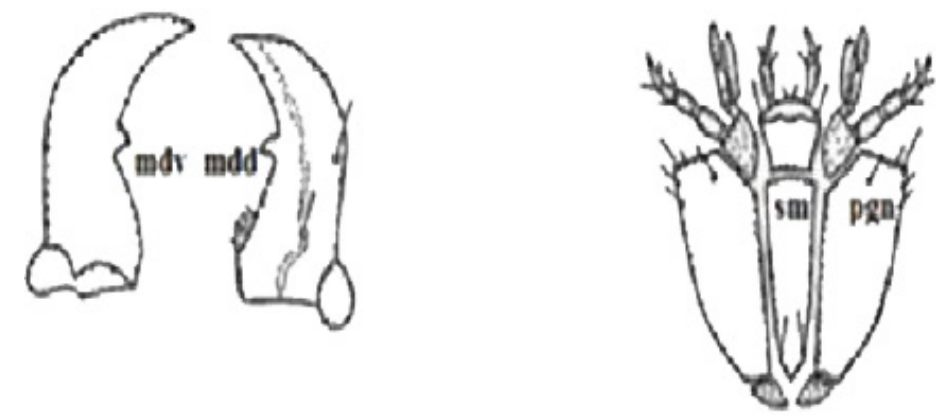

Figure 3. Mandible of the final instar larva of Glyphonix bimarginatus (Schaeffer) ( $\mathrm{mdd}=$ mandible dorsal side, $\mathrm{mdv}=$ mandible ventral side) A. Ventral mouth parts of the final instar larva of Glyphonix bimarginatus (sm=submentum, pgn=post gena) $B$. Credits: Dakshina R. Seal, UF/IFAS
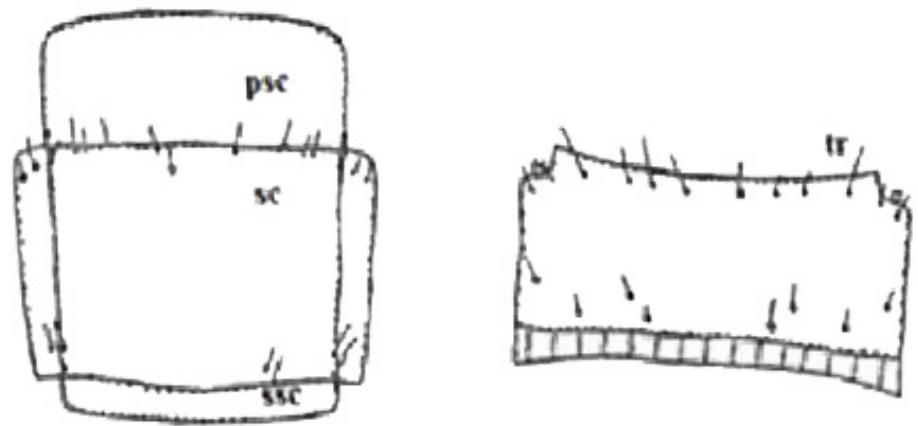

Figure 4. Pronotum of final instar larva of Glyphonix bimarginatus (Schaeffer) ( $\mathrm{psc}=$ pre-scutellar sulcus, sc=scutellar sulcus, ssc=scutoscutellar sulcus) (A). First abdominal tergite of final instar larva of Glyphonix bimarginatus (tr=tergum) (B).

Credits: Dakshina R. Seal, UF/IFAS 

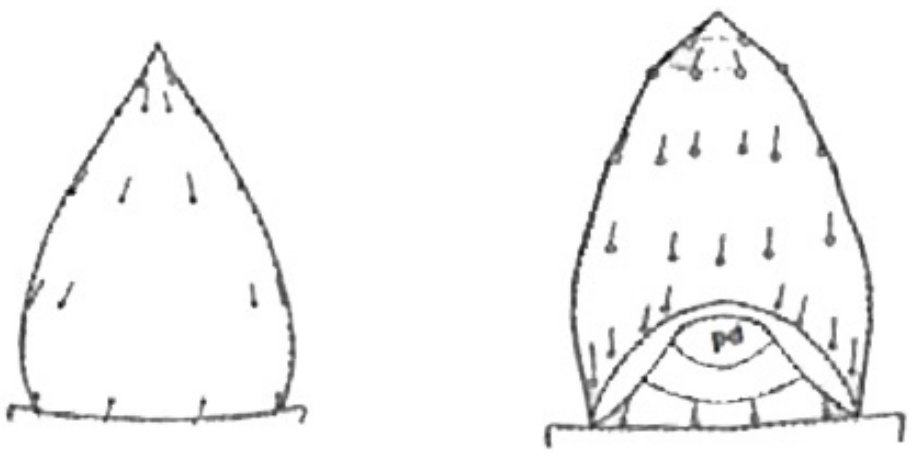

Figure 5. Ninth abdominal segment of final instar larva of Glyphonix bimarginatus (Schaeffer), dorsal view (A). Ninth abdominal segment, of final instar larva of Glyphonix bimarginatus ventral view (pd=pseudopod) (B).

Credits: Dakshina R. Seal, UF/IFAS

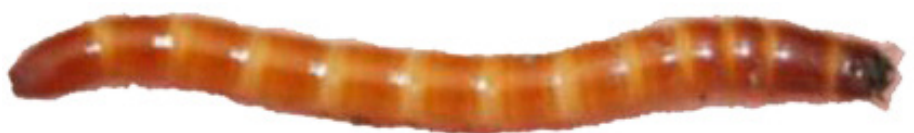

\section{$8 \mathrm{~mm}$}

Figure 6. Third instar larva of Glyphonix bimarginatus (Schaeffer). Credits: Dakshina R. Seal, UF/IFAS

\section{Pupae}

Pupation takes place in a small cell in the soil within 50 to $100 \mathrm{~cm}$ of the soil surface. The root zone is considered as preferred pupation site for Glyphonix bimarginatus. The pupa measures 4 to $12 \mathrm{~mm}$ in length (Seal 1990).

\section{Seasonal Abundance}

Glyphonix bimarginatus occurs year round in regions where sweet potato, sugarcane and peanut are grown. Cherry (2007) reported significantly lower abundance of Glyphonix bimarginatus in summer than other seasons. Based on corn-wheat bait samples, larval populations were highest in February and March in Florida. Highest number of adult population observed in spring and early summer that declines in late summer and fall in Florida (Genung 1972).

\section{Hosts}

Glyphonix bimarginatus is a polyphagous insect pest that feeds on sweet potato, sugarcane and peanut. The larvae have been collected from sweet potato (Willis et al. 2010a), peanut (Herbert et al. 1992), and sugarcane (Hall 1988; Cherry and Stansly 2008), using corn-wheat baits.

\section{Economic Importance}

Glyphonix bimarginatus feeding injury appears as tiny, shallow holes that are insignificant on crop hosts. In the instance of high population abundance there can be multiple shallow stipple-like holes on one potato which can reduce quality. These tiny holes can be used as entry points of plant pathogenic microbes in the soil. Very little information is available on their biology, behavior, spatial distribution and economic importance (Seal 1990; Cherry and Stansly 2008), and they are not generally considered an important pest of root and vegetable crops.

\section{Management}

Glyphonix bimarginatus is commonly found in organic soil alone or with other wireworms in field. Little published information has been reported about its management (Seal 1990). Black light traps and sticky traps are two effective traps to evaluate the adult population in an infected field. Thorough soil preparation by multiple disking significantly reduces Glyphonix bimarginatus populations in crop fields. Fields maintained with proper sanitation reduces abundance of this wireworm (Genung 1988; Seal 1990).

\section{Selected References}

Chalfant RB, Jansson RK, Seal DR, Schalk JM. 1990.

"Ecology and management of sweet potato insects." Annual Review of Entomology 35: 157-180.

Cherry R. 2007. "Seasonal population dynamics of wireworms (Coleoptera: Elateridae) in Florida sugarcane fields." Florida Entomologist 90(3): 426-430.

Cherry R, Stansly P. 2008. "Abundance and spatial distribution of wireworms (Coleoptera: Elateridae) in Florida sugarcane fields on muck versus sandy soils." Florida Entomologist 91(3): 383-387.

Deen OT, Cuthbert Jr. FP 1955. “The distribution and relative abundance of wireworms in potato-growing areas of the southeastern states." Journal of Economic Entomology 48: 191-193.

Genung WG. 1972. "Seasonal occurrence of click beetles (Coleoptera: Elateridae) in the Everglades as measured by two types of traps." Florida Entomologist 55(1): 35-41.

Hall DG. 1988. "Insects and mites associated with sugarcane in Florida." Florida Entomologist 71(2): 138-150.

Seal DR. 1990. The biology of wireworms affecting sweet potatoes in Georgia. Ph. D. Dissertation, Department of Entomology, University of Georgia.

Willis RB, Abney MR, Kennedy GG. 2010a. "Survey of wireworms (Coleoptera: Elateridae) in North Carolina 
sweet potato field and seasonal abundance of Conoderus vespertinus." Horticultural Entomology 103(4): 1268-1276.

Willis RB, Abney MR, Holmes GJ, Schultheis JR, Kennedy GG. 2010b. "Influence of preceding crop on wireworm

(Coleoptera: Elateridae) abundance in the coastal plain of North Carolina." Journal of Economic Entomology 103(6):

2087-2093. 